\title{
PENYIMPANGAN SOSIAL DALAM PRILAKU SEKS BEBAS DIKALANGAN REMAJA
}

\author{
Dr. Syahrul Akmal Latif, M.Si \\ Muhammad Zulherawan, S.Sos., M.Sc.Soc
}

\begin{abstract}
Social deviations in free sex behavior among adolescents is quite alarming because they are seen as bad behavior and contrary to the norms in society. The purpose of this study is to seek solutions to the problem of social deviations of free sex among adolescents by looking at the factors and things that underlie free sex behavior that occurs by departing from theological and sociological analysis and also using the Differential Association theory by Sutherland which explains the process of occurrence deviant behavior. In this study the authors use the method of literature study of various thoughts and previous studies that have been conducted. As for the discussion of this study, the writer took three discussions which became an outline for the author, namely: 1. Knowledge of adolescents about free sex, 2. Free sex behavior among adolescents, and 3. Factors causing free sex among adolescents. So based on this research it is expected to be a solution for the political elite, government, academics and society especially parents to be more together to protect teenagers from the influence of the phenomenon of free sex among adolescents.
\end{abstract}

Keywords: Social Irregularities, Free Sex, Teenagers

\section{PENDAHULUAN}

Di zaman yang semakin berkembang semakin beragam pula tingkah laku serta masalah sosial yang terjadi di masyarakat terutama masalah remaja. Perkembangan teknologi sekarang ini telah banyak memberi pengaruh buruk bagi remaja sehingga menyebabkan terjadinya kenakalan remaja. Masa remaja merupakan masa dimana seorang individu mengalami peralihan dari satu tahapke tahap berikutnya dan mengalami perubahan baik emosi, tubuh, minat, pola perilaku, dan juga penuh dengan masalah-masalah (Hurlock, 2011). Seks bebas merupakan hubungan yang dilakukan oleh laki-laki dan perempuan tanpa adanya ikatan perkawinan. (Desmita, 2005).

Masa remaja merupakan periode terjadinya pertumbuhan dan perkembangan baik secara fisik, psikologis maupun 
intelektual. Sifat khas remaja yang memiliki rasa keingintahuan yang besar, menyukai petualangan dan tantangan serta cenderung berani menanggung resiko tanpa pertimbangan yang matang. Salah satu permasalahan yang terjadi pada masa remaja adalah perilaku seks bebas. Perilaku seks bebas merupakan salah satu akibat dari pergaulan bebas. Permasalahan ini cenderung dilakukan oleh kelompok remaja tengah dan remaja akhir. Remaja tengah (1518 tahun) merupakan masa-masa ingin mencari identitas diri, tertarik dengan lawan jenis, timbul perasaan cinta dan mulai berkhayal mengenai hal-hal yang berkaitan dengan seksual. Remaja akhir (19-21 tahun) merupakan remaja yang mengungkapkan kebebasan diri dan mewujudkan perasaan cinta yang dirasakannya (Kemenkes RI, 2015).

Kematangan fungsi seksual remaja akan menimbulkan dorongan seksual yaitu keinginan untuk mendapatkan kepuasan secara seksual melalui perilaku seksual. Perilaku seks bebas yang dilakukan oleh remaja tidak terlepas dari kurangnya pengetahuan remaja tentang perilaku seksual, paparan pornografi dan pengaruh teman sebaya terbukti menjadi faktor yang paling dominan dalam mempengaruhi perilaku seksual pada remaja (Lubis, 2017).

Kasus tentang kenakalan di Indonesia pada umumnya identik dengan remaja yang berada di kisaran usia 15 tahun dan salah satu bentuk kenalan remaja adalah seks bebas. Hal ini didukung dengan ditemukannya $39 \%$ remaja perempuan dan 57\% remaja laki-laki melakukan petting (Andayani, 2005). Fenomena Seks Bebas dan kecenderungan terhadap seks di kalangan remaja terjadi dalam bentuk menonton film porno 97\%, ciuman, petting, seks oral $93,7 \%$, remaja SMP dan SMU tidak perawan/perjaka lagi $62,7 \%$, remaja SMP dan SMU pernah Aborsi 21,2\% (KPAI, 2016).

Berdasarkan Jurnal yang ditulis Andayani (2005), yang telah dilakukan bahwa ketika mulai beranjak dewasa (usia 18), survei menunjukkan bahwa lebih dari $60 \%$ individu pernah melakukan hubungan seks. Belakangan ini memang hubungan seks bebas menjadi fenomena yang melanda kaum remaja. Seks bebas sendiri mencapai 18,3\%. Pada tahun 2010, hamil di luar nikah karena diperkosa sebanyak 3,2\%; karena sama-sama mau sebanyak $12,9 \%$ dan tidak terduga sebanyak $45 \%$. Seks bebas sendiri mencapai $22,6 \%$. Selain itu, menurut data yang diperoleh dari Media Indonesia, ratarata terdapat $17 \%$ kehamilan yang terjadi per tahun, merupakan kehamilan yang tidak diinginkan.

Prevalensi kasus seks pra nikah remaja menurut BPS, BKKBN, KEMENTERIAN KESEHATAN RI, ICF INTERNATIONAL (2013), sebanyak $14,6 \%$ terjadi pada remaja perempuan usia 15-19 tahun. Alasan hubungan seks bebas tersebut sebagian besar karena penasaran/rasa ingin tahu $(57,5 \%)$, terjadi begitu saja pada perempuan (38\%), dan dipaksa oleh pasangan $(12,6 \%)$ pada perempuan. Data kasus pengaduan anak pada klaster pornografi dan cyber crime pada tahun 2016 sebanyak 414 anak, yaitu anak korban kejahatan seksual online sebesar 94 orang, anak pelaku kejahatan seksual online sebesar 72 orang, anak 
korban pornografi dari media sosial sebesar 168 orang, anak pelaku kepemilikan media pornografi (HP/Video) sebesar 80 orang. Data kasus anak korban tayangan dan pergaulan seks bebas di Indonesia sebesar 157 orang dan anak korban pernikahan di bawah umur sebesar 10 orang (KPAI, 2016).

Menurut Survei Demografi dan Kesehatan Indonesia BPS, BKKBN, KEMENTERIAN KESEHATAN RI, ICF INTERNATIONAL (2013), salah satu faktor yang diperkirakan menjadi penyebab utama meningkatnya perilaku seksual pada anak usia sekolah adalah perilaku pacaran. Sebagian remaja jaman sekarang menganggap bahwa hubungan seksual pada masa pacaran adalah hal yang sudah biasa dan wajar. Potensi terjadinya perilaku seks bebas dikalangan remaja lebih besar, karena belum mengetahui dampak perilaku seks diluar nikah dan melakukan perilaku seks yang tidak aman. Perilaku tersebut jika tidak segera ditangani akan berdampak negatif bagi kesehatan reproduksi remaja, seperti: kehamilan yang tidak diinginkan (KTD), aborsi, tertular penyakit menular seksual dan HIV/AIDS, hingga terjadi kematian (Setiyaningrum, 2015).

\section{METODE PENELITIAN}

Metode yang digunakan dalam kajian ini yaitu penelitian kepustakaan dan studi pustaka/riset pustaka meski bisa dikatakan mirip akan tetapi berbeda. Studi pustaka adalah istilah lain dari kajian pustaka, tinjauan pustaka, kajian teoritis, landasan teori, telaah pustaka (literature review), dan tinjauan teoritis (Baswori. Kasinu, 2007). Yang dimaksud penelitian kepustakaan adalah penelitian yang dilakukan hanya berdasarkan atas karya tertulis, termasuk hasil penelitian baik yang telah maupun yang belum dipublikasikan (Widodo, 2004).

Dalam Narbuko. Achmadi, (2005) meskipun merupakan sebuah penelitian, penelitian dengan studi literatur tidak harus turun ke lapangan dan bertemu dengan responden. Data-data yang dibutuhkan dalam penelitian dapat diperoleh dari sumber pustaka atau dokumen. Menurut (Zed, 2014), pada riset pustaka (library research), penelusuran pustaka tidak hanya untuk langkah awal menyiapkan kerangka penelitian (research design) akan tetapi sekaligus memanfaatkan sumber-sumber perpustakaan untuk memperoleh data penelitian.

Berangkat fenomena yang ada, maka tulisan dalam penelitian ini menggunakan metode studi pustaka. Penulis melakukan pengembangngan kajian teoritis dengan memperbanyak informasi, mencari hubungan ke berbagai sumber, membandingkan, dan menemukan hasil atas dasar data sebenarnya (tidak dalam bentuk angka). Dalam tulisan ini, penulis selanjutnya melakukan kajian teologissosiologis terhadap pergaulan seks bebas remaja. Sumber-sumber pustaka yang digunakan dalam kajian ini adalah meliputi pemikiran-pemikiran dalam berbagai sumber buku, dan kajian-kajian yang telah dilakukan dan dipublikasikan dalam jurnal ilmiah.

Berkaitan dengan perilaku menyimpang, teori-teori sosiologi baik yang termasuk dalam kategori klasik maupun modern telah memberikan penjelasan yang 
cukup memadai untuk dijadikan pijakan dalam memahami sebab-sebab terjadinya perilaku menyimpang. Perilaku menyimpang identik dengan remaja dengan segala bentuk jenisnya. Dalam kajian ini fokusnya berkaitan serta terkait dengan perilaku menyimpang dalam bentuk seks bebas.

Pada tulisan ini, Penulis menggunakan teori asosiasi diferensial yang dikemukan oleh Edward H.Sutherland. Dimana menurut Sutherland menjelaskan bahwa perilaku menyimpang adalah perilaku yang dihasilkan oleh hasil belajar dari lingkungan. Dalam hal ini kenapa peneulis memakai teori asosiasi diferensial dikarenakan, remaja banyak melakukan perilaku menyimpang, khususnya terkait seks bebas. Berikut akan dijelaskan terkait hal-hal yang mencakup dalam kajian ini dan teori yang digunakan.

\section{TEORI}

ASSOSIATION

DIFFERENTIAL SUTHERLAND

Dalam penjelasannya Edward H.Sutherland memandang bahwa perilaku menyimpang bersumber pada pergaulan yang berbeda (differential assosiation). Artinya seorang individu mempelajari sebuah perilaku menyimpang dari interaksinya dengan seorang individu yang berbeda latarbelakang asal, kelompok, atau budaya. Dikatakan bahwa penyimpangan itu dipelajari melalui proses alih budaya. Melalui proses belajar ini, seseorang mempelajari suatu perilaku menyimpang atau sub kebudayaan menyimpang. Misalnya, seorang anak yang sering disiksa sejak kecil cenderung mengulangi perbuatan menyimpang tersebut terhadap orang lain. Dari interaksi dengan orang-orang tersebut, individu mungkin saja memperoleh pembelajaran tentang suatu sub budaya yang menyimpang. perilaku meyimpang yang terjadi pada masyarakat kita akhir-akhir ini terjadi karena adanya proses pembelajaran secara sengaja atau tidak disengaja atas suatu perilaku menyimpang diakibatkan kemajuan teknologi informasi. Menurut Narwoko, (2004), apabila dirinci, asosiasi diferensial memiliki sembilan proposisi, antara lain adalah sebagai berikut:

1. Perilaku menyimpang merupakan hasil dari proses belajar atau yang dipelajari. Hal ini berarti bahwa penyimpangan bukan diwariskan atau diturunkan dan bukan hasil dari intelegensi yang rendah atau karena kerusakan otak.

2. Perilaku menyimpang dipelajari oleh seseorang dalam interaksinya dengan orang lain antar individu dan melibatkan proses komunikasi yang intens.

3. Perilaku menyimpang terjadi di dalam kelompok personal yang intim dan akrab.

4. Ada hal-hal yang dipelajari dalam proses terbentuknya perilaku menyimpang, yaitu berupa teknisteknis dan petunjuk-petunjuk khusus tentang motif, dorongan, dan sikapsikap dalam perilaku menyimpang.

5. Petunjuk-petunjuk khusus tentang motif dan dorongan untuk melakukan perilaku yang menyimpang dipelajari dari definisi tentang norma yang baik atau buruk. 
6. Seseorang melakukan penyimpangan karena dianggpa lebih menguntungkan daripada tidak melanggar.

7. Terbentuknya asosiasi deferensiasi sangat bervariasi tergantung dari frekuensi, durasi, prioritas, dan intensitas.

8. Proses mempelajari perilaku menyimpang melibatkan kelompok yang memiliki pola-pola menyimpang.

9. Meskipun perilaku menyimpang merupakan ekspresi dari kebutuhan dan nilai masyarakat umum, tetapi perilaku menyimpang itu tidak dapat dijelaskan melalui kebutuhan dan nilai umum tersebut

\section{PENYIMPNGAN SOSIAL REMAJA}

Dalam perspektif sosiologi perilaku menyimpang remaja terjadi karena terdapat penyimpangan perilaku dari berbagai aturanaturan sosial ataupun dari nilai dan norma sosial yang berlaku. Perilaku menyimpang dapat dianggap sebagai sumber masalah karena dapat membahayakan tegaknya sistem sosial. Penggunaan konsep perilaku menyimpang secara tersirat mengandung makna bahwa ada jalur baku yang harus ditempuh. Perilaku remaja yang tidak melalui jalur tersebut berarti telah menyimpang atau telah terjadi kenakalan remaja.

Penyimpangan secara normatif didefinisikan sebagai penyimpangan terhadap norma, di mana penyimpangan itu adalah terlarang bila diketahui dan mendapat sanksi. Jumlah dan macam penyimpangan dalam masyarakat adalah relatif tergantung dari besarnya perbedaan Penyimpangan adalah relatif terhadap norma suatu kelompok atau masyarakat. Karena norma berubah maka penyimpangan berubah.

Proses sosialisasi terjadi dalam kehidupan sehari-hari melalui interaksi sosial dengan menggunakan media atau lingkungan sosial tertentu. Oleh sebab itu, kondisi kehidupan lingkungan tersebut akan sangat mewarnai dan mempengaruhi input dan pengetahuan yang diserap oleh setiap remaja. Karena itulah dalam membahas perilaku penyimpangan remaja, penulis menitikberatkan pada pendekatan sistem, yaitu perilaku individu sebagai masalah sosial yang bersumber dari sistem sosial terutama dalam pandangan disorganisasi sosial sebagai sumber masalah. Hal ini dapat dijelaskan bahwa pada umumnya para remaja yang mengalami gejala disorganisasi sosial dalam keluarga misalnya, maka norma dan nilai sosial menjadi kehilangan kekuatan mengikat. Dengan demikian control sosial menjadi lemah, sehingga memungkinkan terjadinya berbagai bentuk penyimpangan perilakunya.

Menurut Kartono, (2009), kenakalan remaja atau Juvenile delinguency merupakan gejala patologis sosial pada remaja yang disebabkan oleh satu bentuk pengabaian sosial. Akibatnya mereka mengembangkan bentuk perilaku yang menyimpang, sementara Santrock (2009) mengatakan kenakalan remaja merupakan kumpulan dari berbagai perilaku remaja yang tidak dapat diterima secara sosial hingga terjadi tindakan kriminal. Kenakalan 
remaja adalah kelainan tingkah laku/tindakan remaja yang bersifat anti sosial, melanggar norma sosial, agama serta ketentuan hukum yang berlaku dalam masyarakat (Mubarak, 2009).

Mubarak (2009) selanjutnya mengatakan kenakalan remaja biasanya dilakukan oleh remaja-remaja yang gagal dalam menjalani proses-proses perkembangannya, baik pada saat remaja maupun pada saat kanak-kanak. secara psikologis kenakalan remaja merupakan wujud dari konflik-konflik yang tidak terselesaikan dengan baik pada masa kanakkanak maupun pada masa remaja, perlakuan kasar dan tidak menyenangkan dari lingkungannya, seperti kondisi ekonomi yang membuatnya merasa rendah diri dan sebagainya. Masalah sosial yang dikategorikan perilaku menyimpang yaitu kenakalan remaja. Perilaku kenakalan remaja dapat disebabkan oleh faktor dari remaja itu sendiri (internal) maupun faktor dari luar (ekternal), faktor internal diantaranya ialah :

1. Krisis identitas, yaitu perubahan biologis dan sosiologis pada remaja memungkinkan terjadinya dua bentuk integrasi. Pertama terbentuknya perasaan akan konsistensi dalam kehidupannya. Kedua, tercapainya identitas peran. Kenakalan remaja terjadi karena remaja gagal mencapai masa integrasi kedua.

2. Kontrol diri yang lemah, dimana remaja tidak dapat mempelajari dan membedakan tingkah laku yang dapat diterima dengan yang tidak dapat diterima sehingga akan terseret pada prilaku "nakal".

Begitupun bagi mereka yang telah mengetahui perbedaan dua tingkah laku tersebut, namun tidak bisa mengembangkan kontrol diri untuk bertingkah laku sesuai dengan pengetahuannya. Adapun yang termasuk faktor eksternal terjadinya kenakalan remaja yaitu sebagai berikut :

a. Keluarga, meliputi perceraian orang tua, tidak adanya komunikasi antar anggota keluarga, atau perselisihan antar anggota keluarga bisa memicu prilaku negatif pada remaja. Pendidikan yang salah dalam keluarga, seperti terlalu memanjakan anak, tidak memberikan pendidikan agama atau penolakan terhadap eksistensi anak bisa menjadi penyebab kenakalan remaja.

b. Teman sebaya yang kurang baik

c. Masyarakat/lingkungan tempat tinggal yang kurang baik.

Penggolongan dan Bentuk-bentuk Kenakalan Remaja menurut Gumarso (1988) membagi dari segi hukum dalam dua kelompok yang berkaitan dengan normanorma hukum, yaitu kenakalan yang bersifat amoral dan sosial. Pelanggaran kenakalan tidak diatur dalam undang-undang sehingga tidak dapat atau sulit digolongkan dalam pelanggaran hukum. Kenakalan yang bersifat melanggar hukum dengan penyelesaian sesuai dengan undang-undang dan hukum yang berlaku, sama dengan perbuatan melanggar hukum bila dilakukan oleh orang dewasa (Mubarak, 2009). 
Menurut bentuknya, Sunarwiyati (1985) membagi kenakalan remaja ke dalam tiga tingkatan yaitu kenakalan biasa, seperti suka berkelahi, suka keluyuran, membolos sekolah, pergi dari rumah tanpa pamit; kenakalan remaja yang menjurus pada pelanggaran dan kejahatan, seperti mengendarai mobil tanpa SIM, mengambil barang orang tua tanpa izin; kenakalan khusus, seperti penyalahgunaan narkotika, hubungan seks di luar nikah, pemerkosaan, menggugurkan kandungan (aborsi), berjudi, membunuh dan lain-lain. Perilaku menyimpang atau kejahatan dianggap sebagai fakta sosial yang normal jika dalam batas-batas tertentu. Sebaliknya dari perilaku yang dianggap normal merupakan perilaku nakal/jahat, yaitu perilaku yang sengaja meninggalkan keresahan pada masyarakat (Mubarak, 2009).

Berbagai macam bentuk kenakalan remaja saat ini menurut Tanjung (2007) mengacu pada perilaku seks bebas/freesex. Perilaku seks bebas memiliki beberapa macam bentuk yaitu hubungan seks bebas, kumpul kebo, pelacuran, gigolo, homoseksual dan perkosaan. Bentuk perilaku seks bebas yang banyak dilakukan oleh remaja saat ini yaitu hubungan seks bebas.

\section{SEKS BEBAS}

Seks bebas merupakan kebiasaan melakukan seksual secara bebas dilakukan oleh mereka yang menentang atau merasa enggan jika diri mereka terikat dalam suatu pernikahan yang suci. Orang yang telah mempertaruhkan hawa nafsunya sendiri, akan merasa sangat tidak puas jika menyalurkan nafsu biologisnya kepada istri atau suami sahnya saja. tujuan seks adalah sebagai sarana untuk memperoleh kepuasan dan relaksasi dalam kehidupan (bagi manusia). Hubungan seks yang dilakukan diluar pernikahan disebut seks bebas (free sex).

Seks menurut Kartono (2009) merupakan energi psikis yang ikut mendorong individu manusia untuk bertingkah laku. Tidak Cuma bertingkah laku di dalam seks saja yaitu menjalin hubungan seksual atau bersenggama, akan tetapi juga melakukan kegiatan-kegiatan abnormal. Sedangkan Desmita (2005) seks bebas adalah segala cara mengepresikan dan melepaskan dorongan seksual yang berasal dari kematangan organ seksual, seperti berkencan intim, bercumbu, sampai melakukan kontak seksual, tetapi perilaku tersebut dinilai tidak sesuai dengan norma karena remaja belum memiliki pengalaman tentang seksual. Dengan demikian, pengertian seks bebas adalah segala perbuatan tingkah laku yang didorong oleh keinginan seksual terhadap lawan jenis maupun sesama jenis (homoseksual) yang dilakukan di luar pernikahan dan bertentangan dengan norma-norma tingkah laku seksual dalam masyarakat yang tidak bisa diterima secara umum.

Hubungan seks bebas pada umumnya berawal dari masa pacaran. Pada masa pacaran ini hubungan intim mulai dilakukan kalangan remaja. Baik pelajar, mahasiswa, pemuda-pemudi tidak sekolah, remaja yang tinggal di kota atau di desa. Waktu pacaran tergiur cumbu rayu, peluk cium dan bila gejolak nafsu tidak terkendali berlanjut ke 
hubungan badan. Tempatnya bisa di Bioskop yang gelap, di tempat Rekreasi, Kost, di Rumah saat rumah sepi, dan bahkan sengaja menginap di Hotel. Remaja putri makin sulit mengelak, bila bentuk rayuan gombal sang pacar minta bukti ketulusan cintanya dengan berhubungan seks. Inilah yang sering kali disalahartikan kalangan remaja.

Hubungan seksual yang dilakukan oleh sebagian besar remaja pada umumnya akan menyebabkan remaja hamil bebas. Kehamilan yang dialami beberapa remaja akibat telah melakukan hubungan seks sebelum menikah (Premarital Sex) disikapi dengan berbagai tindakan seperti mengugurkan kandungan/aborsi dan atau menikah dengan pasangan seksnya. Masih merupakan fakta yang menyedihkan bahwa hampir seperempat kehamilan di negara ini diakhiri dengan aborsi elektif. Aborsi elektif atau sukarela adalah penghentian kehamilan sebelum viabilitas atas permintaan wanita yang berangkutan tetapi bukan karena alasan gangguan kesehatan pada ibu atau penyakit pada janin. Menurut American College of Obstetricans and Gynecologits (2007) "cara yang paling efektif untuk menurunkan angka aborsi adalah mencegah kehamilan yang tak diinginkan dan tak diharapkan". Suatu hal yang penting bahwa sikap, kepercayaan dan politik yang bersifat negatif mengenai pelayanan keluarga berencana dan pendidikan seks telah berperan dalam memperbesar angka aborsi menjadi sekitar 1 juta setiap satu tahunnya di Amerika Serikat (Chunigham, 2014).

\section{PEMBAHASAN}

\section{A. Pengetahuan Remaja Tentang Seks Bebas}

Pendidikan seks merupakan salah satu cara untuk mengurangi atau mencegah penyalahgunaan seks, khususnya untuk mencegah dampak-dampak negatif yang tidak diharapkan seperti kehamilan yang tidak direncanakan, penyakit menular, depresi, dan perasaan berdosa. Selain itu dengan adanya pengaruh dalam pemberian pendidikan seks bisa di manfaatkan oleh pendidik di masing-masing sekolah untuk memberikan informasi mengenai kesehatan reproduksi remaja agar remaja memiliki bekal pengetahuan yang baik dan sikap positif dalam menanggapi permasalahan seks bebas dikalangan remaja (Sarwono, 2010).

Hal tersebut sesuai dengan pendapat Mubarak (2009) menyatakan bahwa tidak dapat dipungkiri bahwa makin tinggi pendidikan seseorang semakin mudah pula mereka menerima informasi, dan pada akhirnya makin banyak pula pengetahuan yang dimilikinya. Sebaliknya, jika seseorang tingkat pendidikannya rendah, akan menghambat perkembangan sikap seseorang terhadap penerimaan informasi nilai nilai yang baru diterimanya.

Menurut Sumiati (2009) menyatakan pendidikan seks dapat memberikan pengetahuan tentang kesalahan dan penyimpangan seksual agar individu dapat menjaga diri dan melawan eksploitasi yang dapat mengganggu kesehatan fisik dan mentalnya dan dapat membentuk sikap serta memberikan pengertian terhadap seks dalam 
semua manifestasi yang bervariasi. Teori tersebut diperkuat dengan penelitian Boediono (2010) bahwa setelah di berikan pendidikan kesehatan seks berpengaruh terhadap tingkat pengetahuan dan sikap remaja tentang perilaku seks bebas di tunjukan dengan nilai signifikansi atau $\mathrm{P}$ value $=0,000<0,05$ begitu pula dengan penelitian yang dilakukan oleh Surya dan Indrawati (2011) menyatakan bahwa adanya perbedaan yang bermakna pada pengetahuan remaja tentang kesehatan reproduksi sebelum dan sesudah penyuluhan (p-value $0,000)$. Melalui pendidikan seks kita dapat memberitahu remaja bahwa seks adalah sesuatu yang alamiah dan wajar terjadi pada setiap orang, selain itu remaja juga dapat diberitahu mengenai berbagai perilaku seksual berisiko sehingga mereka dapat menghindarinya (Wdyastuti, 2009)

Penelitian tersebut berbeda dengan hasil penelitian penelitian Suwarni (2009) yang menyatakan pengaruh terbesar bersumber dari perilaku teman sebaya yang bisa mempengaruhi pengetahuan, sikap dan perilaku seksual remaja baik secara langsung sebesar $(20,2 \%)$ maupun tidak langsung melaui niat berperilaku seksual $(14,24 \%)$. Beberapa pihak masih tidak setuju dengan pendidikan seks, karena dikhawatirkan dengan pendidikan seks, anak-anak yang belum saatnya tahu tentang seks jadi mengetahuinya dan karena dorongan keingintahuan yang besar yang ada pada remaja, mereka jadi ingin mencobanya hal ini dikarenakan masyarakat masih menganggap tabu jika membicarakan tentang seks (BKKBN, 2010).
Sikap memiliki empat fungsi diantaranya fungsi pertahanan ego yaitu sikap yang diambil untuk melindungi dirinya dari kecemasan atau ancaman hargadirinya serta fungsi pengetahuan individu mempunyai dorongan untuk ingin mengerti dengan pengalamanpengalamannya yang di wujudkan dalam kehidupan sehari-hari maka seseorang yang memiliki sikap positif akan mendapatkan kedua fungsi tersebut. Sikap positif mengenai pencegahan seks bebas dapat melindungi remaja dari perilaku sek bebas sehingga dapat terhindar dari dampak seks bebas (Wawan dan Dewi, 2010). Diperkuat dengan penelitian Suwarni (2009) yang menyatakan bahwa ada hubungan antara sikap tentanng perilaku seksual dengan niat berperilaku seks dengan keeratan hubungan cukup yang artinya semakin permisif sikap remaja tentang perilaku seks bebas maka niat remaja berperilaku seksual akan semakin beresiko terhadap kehamilan tidak dikehendaki (KTD), penyakit menular seksual, HIV dan AIDS.

Menurut Azwar (2011) pembentukan atau faktor yang mempengaruhi sikap adalah pengalaman pribadi, pengaruh orang lain yang dianggap penting, pengaruh kebudayaan, media massa, lembaga pendidikan, agama dan factor emosional. Salah satu faktor yang mempengaruhi adalah pengaruh oranglain yang dianggap penting, orang lain yang dimaksud salah satunya adalah orang tua. Hal ini diperkuat dengan penelitian Suwarni (2009) secara statistik ada hubungan ada pengaruh monitoring parental terhadap perilaku seksual remaja baik secara langsung (sebesar 10,6\%) maupun tidak langsung melalui variabel 
sikap tentang perilaku seks bebas (sebesar 9,28\%), pada responden dengan monitoring parental tinggi maka sikap dan perilaku remaja termasuk dalam kategori tidak beresiko.

\section{B. Prilaku Seks Bebas Dikalangan Remaja}

Perilaku seks bebasdapat dikelompokkan menjadi empat kategori, yaitu berciuman, berpelukan, bercumbu (petting), dan berhubungan badan. Sebagian besar Perilaku seks bebast ersebut dilakukan di rumah, rumah kos, lingkungan kampus, dan tempat-tempat lainnya seperti hotel, losmen dan tempat penginapan lainnya. Bahkan ada juga yang melakukannya di dalam mobil pada waktu jalan-jalan. Perilaku hubungan seks bebas di kalangan remaja paling banyak dilakukan sepulang dari tempat hiburan malam, biasanya cewekcewek yang sudah mabok akan sangat gampang untuk ditiduri oleh teman-teman lelakinya.

Perilaku seks bebas dapat didefinisikan sebagai bentuk perilaku yang didorong oleh hasrat seksual baik dengan lawan jenis maupun sejenis. Menurut Simkin, Perilaku seks bebas adalah segala tingkah laku yang didorong oleh hasrat seksual baik dengan lawan jenis maupun dengan sesama jenis. Bentuk tingkah laku ini beraneka ragam mulai dari perasaan tertarik hingga tingkah laku berkencan, bercumbu dan bersenggama (Amrillah, 2006).

Tujuan seksual disamping untuk kesenangan atau kepuasan seksual atau juga pengendoran ketegangan seksual. Kartono juga menjelaskan bahwa seks adalah mekanisme bagi manusia untuk melanjutkan keturunan. Seks bukan hanya perkembangan dan fungsi primer saja, tetapi juga termasuk gaya dan cara berperilaku kaum pria dan wanita dalam hubungan interpersonal atau sosial (Amrillah, 2006).

Perkembangan fisik termasuk organ seksual yaitu terjadinya kematangan serta peningkatan kadar hormon reproduksi atau hormon seks baik pada laki-laki maupun pada perempuan yang akan menyebabkan perubahan Perilaku seks bebas remaja secara keseluruhan. Pada kehidupan psikologis remaja, perkembangan organ seksual mempunyai pengaruh kuat dalam minat remaja terhadap lawan jenis. Terjadinya peningkatan perhatian remaja terhadap lawan jenis sangat dipengaruhi oleh faktor perubahan-perubahan fisik selama periode puberitas (Santrock, 2009).

Remaja perempuan lebih memperlihatkan bentuk tubuh yang menarik bagi remaja laki-laki, demikian pula remaja pria tubuhnya menjadi lebih kekar yang menarik bagi remaja perempuan (Rumini dan Sundari, 2004). Pada masa remaja rasa ingin tahu terhadap masalah seksual sangat penting dalam pembentukan hubungan yang lebih matang dengan lawan jenis. Matangnya fungsi-fungsi seksual maka timbul pula dorongan-dorongan dan keinginan-keinginan untuk pemuasan seksual. Sebagian besar dari remaja biasanya sudah mengembangkan perilaku seksualnya dengan lawan jenis dalam bentuk pacaran atau percintaan. Bila ada kesempatan para remaja melakukan sentuhan fisik, mengadakan pertemuan untuk bercumbu 
bahkan kadang-kadang remaja tersebut mencari kesempatan untuk melakukan hubungan seksual. Meskipun fungsi seksual remaja perempuan lebih cepat matang dari pada remaja laki-laki, tetapi pada perkembangannya remaja laki-laki lebih aktif secara seksual dari pada remaja perempuan. Banyak ahli berpendapat hal ini dikarenakan adanya perbedaan sosialisasi seksual antara remaja perempuan dan remaja laki-laki. Bahkan hubungan seks sebelum menikah dianggap "benar" apabila orangorang yang terlibat saling mencintai ataupun saling terikat. Mereka sering merasionalisasikan tingkah laku seksual mereka dengan mengatakan pada diri mereka sendiri bahwa mereka terhanyut cinta. Sejumlah peneliti menemukan bahwa remaja perempuan, lebih daripada remaja laki-laki, mengatakan bahwa alasan utama mereka aktif secara seksual adalah karena jatuh cinta (Santrock, 2009).

Menurut Sarwono (2010), Perilaku seks bebas adalah segala tingkah laku yang didorong oleh hasrat seksual baik yang dilakukan sendiri, dengan lawan jenis maupun sesama jenis tanpa adanya ikatan pernikahan menurut agama. Menurut Stuart dan Sundeen (1999), Perilaku seks bebasyang sehat dan adaptif dilakukan ditempat pribadi dalam ikatan yang sah menurut hukum. Sedangkan Perilaku seks bebas merupakan perilaku seksual yang dilakukan tanpa melalui proses pernikahan yang resmi menurut hukum maupun menurut agama dan kepercayaan masingmasing (Masland, 2004).

Perilaku seks bebas di kalangan remaja dilakukan dengan berbagai tindakan atau Perilaku seks bebas beresiko yang terdiri atas tahapan-tahapan tertentu yaitu dimulai dari berpegangan tangan, cium kering, cium basah, berpelukan, memegang atau meraba bagian sensitif, petting, oral sex, dan bersenggama (sexual intercourse). Perilaku seks bebas pada remaja ini pada akhirnya dapat mengakibatkan berbagai dampak yang merugikan remaja itu sendiri

\section{Faktor Penyebab Seks Bebas Dikalangan Remaja}

Menurut Ghifari (2003) perilaku negatif remaja terutama hubungannya dengan penyimpangan seksualitas, pada dasarnya bukan murni tindakan diri mereka sendiri, melainkan ada faktor pendukung atau yang mempengaruhi dari luar. Faktorfaktor yang menjadi sumber penyimpangan tersebut adalah:

1. Kualitas diri remaja itu sendiri seperti, perkembanggan emosional yang tidak sehat, mengalami hambatan dalam pergaulan sehat, kurang mendalami norma agama, ketidak mampuan menggunakan waktu luang.

2. Kualitas keluarga yang tidak mendukung anak untuk berlaku baik, bahkan tidak mendapatkan kasih sayang dari orang tua dan pergeseran norma keluarga dalam mengembangkan norma positif. Disamping itu keluarga tidak memberikan arahan seks yang baik.

3. Kualitas lingkungan yang kurang sehat, seperti lingkungan masyarakat yang mengalami kesenjangan komunikasi antar tetangga. 
4. Minimnya kualitas informasi yang masuk pada remaja sebagai akibat globalisasi, akibatnya anak remaja sangat kesulitan atau jarang mendapatkan informasi sehat dalam seksualitas.

Menurut sebuah penelitian yang dilakukan oleh Yayasan Keluarga Kaiser (Kaiser Family Foundation) dalam (Dariyo, 2004), hal-hal yang mendorong remaja melakukan hubungan seks di luar pernikahan adalah:

a. Hubungan seks: bentuk penyaluran kasih sayang yang salah dalam masa pacaran.

Seringkali remaja mempunyai pandangan yang salah bahwa masa pacaran merupakan masa di mana seseorang boleh mencintai maupun dicintai oleh kekasihnya. Dalam hal ini, bentuk ungkapan rasa cinta (kasih sayang) dapat dinyatakan dengan berbagai cara, misalnya, pemberian hadiah bunga, berpelukan, berciuman, dan bahkan melakukan hubungan seksual. Dengan anggapan yang salah ini, maka juga akan menyebabkan tindakan yang salah. Karena itu, sebelum pacaran, sebaiknya orang tua wajib memberi pengertian yang benar kepada anak remajanya agar mereka tidak terjerumus pada tindakan yang salah.

b. Kehidupan iman yang rapuh.

Kehidupan beragama yang baik dan benar ditandai dengan pengertian, pemahaman dan ketaatan dalam menjalankan ajaran-ajaran agama dengan baik tanpa dipengaruhi oleh situasi kondisi apapun. Dalam keadaan apa saja, orang yang taat beragama, selalu dapat menempatkan diri dan mengendalika diri agar tidak berbuat hal-hal yang bertentanggan dengan ajaran agama. Dalam hatinya, selalu ingat terhadap Tuhan, sebab mata Tuhan selalu mengawasi setiap perbuatan manusia. Oleh karena itu, ia tak akan melakukan hubungan seksual dengan pacarnya, sebelum menikah secara resmi. Ia akan menjaga kehormatan pacarnya, agar terhindar dari tindakan nafsu seksual sesaat. Bagi individu yang taat beragama, akan melakukan hal itu sebaik-baiknya. Sebaliknya, bagi individu yang rapuh imannya, cenderung mudah melakukan pelanggaran terhadap ajaran-ajaran agamanya. Agama hanya dijadikan sebagai kedok atau topeng untuk mengelabui orang lain (pacar), sehingga tak heran, kemungkinan besar orang tersebut dapat melakukan hubungan seks bebas.

c. Faktor kematangan biologis. Dapat diketahui bahwa masa remaja ditandai dengan adanya kematangan biologis. Dengan kematangan biologis, seorang remaja sudah dapat melakukan fungsi reproduksi sebagai mana layaknya orang dewasa lainnya, sebab fungsi organ seksualnya telah bekerja secara normal. Hal ini membawa konsekuensi bahwa seorang remaja akan mudah terpengaruh oleh stimulasi yang merangsang gairah seksualnya, misalnya, dengan 
melihat film porno dan cerita cabul. Kematangan biologis yang tidak disertai dengan kemampuan mengendalikan diri, cenderung berakibat negatif, yaitu terjadi hubungan seks bebas di masa pacaran remaja. Sebaliknya, kematangan biologis, disertai dengan kemampuan pengendalian diri akan membawa kebahagiaan remaja dimasa depannya, sebab ia tidak akan melakukan hubungan seks bebas.

Kartono, (2009) mengungkapkan bahwa perilaku seks bebas dipengaruhi oleh faktor-faktor :

a. Belum adanya regulasi atau pengaturan terhadap penyelenggaraan hubungan seks dengan peraturan tertentu.

Dorongan seks begitu dasyat dan besar pengaruhnya terhadap manusia. Seks bisa membangun kepribadian, tetapi juga bisa menghancurkan sifat-sifat kemanusiaan.

b. Perubahan sosial

Perkembangan teknologi, ilmu pengetahuan, dan komunikasi menyebabkan perubahan sosial yang demikian cepat pada hampir semua kebudayaan manusia. Perubahan sosial ini mempengaruhi kebiasaan hidup manusia, termasuk mempengaruhi pola-pola seks yang konvensional menjadi keluar dari jalur-jalur konvensional kebudayaan, sehingga bertentangan dengan sistem regulasi seks yang konvensional, dan terjadilah apa yang dinamakan seks bebas. Pelaksanaan seks bebas banyak dipengaruhi oleh penyebab dari perubahan sosial, seperti : urbanisasi, mekanisasi, alat kontrasepsi, pendidikan, demokratisasi fungsi wanita dalam masyarakat dan modernisasi.

Menurut beberapa artikel yang telah di baca di menjadi rujukan faktor yang menjadi subtansi paling utama dibagi menjadi dua faktor yaitu faktor internal dan faktor eksternal, sebagaimana dijelaskan dan dirangkum menjadi sebuah pembahsan yang boleh menjadi landasan kesimpulan dalam pembahasan faktor penyebab seks bebas dikalangan remaja. Adapaun faktor internal dan faktor eksternal tersebut sebagai berikut:

\section{Faktor Internal}

Faktor internal merupakan faktor yang muncul karena adanya dorongan dan kemauan dari individu itu sendiri. Pribadi manusia dapat dipengaruhi oleh sesuatu, karena itu ada usaha untuk membentuk pribadi, membentuk watak atau mendidik watak seseorang. Sejak dahulu diketahui bahwa pribadi tiap individu tumbuh atas dua kekuatan, yaitu kekuatan dari dalam, yang sudah dibawanya sejak lahir atau bisa disebut juga dengan kemampuan dasar dan kemampuan dari luar, yang diterima dan dipelajari individu dari keadaan sekitarnya dia berada. Pada penelitian ini ada dua hal yang secara internal ditemukan dalam mempengaruhi perilaku seks bebas dikalangan remaja, diantaranya:

a. Aspek Perkembangan Alat Seksual (Biologis) 
Perkembangan alat seksual (biologis) merupakan salah satu bentuk ciri-ciri perubahan pada remaja yang nampak dari luar, sehingga secara langsung perubahan yang terjadi dapat dilihat oleh orang lain. Dari hal tersebut tentunya akan memiliki dampak apabila remaja yang mengalami perubahan pada fisiknya atau alat seksualnya (biologis) yang tidak terkontrol dengan baik. Hal ini dapat memancing pemikiran negatif seseorang terhadap remaja yang menyalahgunakan perubahan pada alat seksualnya (biologis). Dalam Rahmawati, (2012) yang menjelaskan bahwa penyebab remaja berperilaku menyimpang yaitu salah satu dikarenakan adanya kualitas dari pribadi remaja itu sendiri, seperti perkembangan emosional yang kurang, adanya hambatan dalam perkembangan hati nurani dan ketidakmampuan dalam mempergunakan waktu luang sehingga lebih memilih kegiatan alternatif yang keliru dan hal tersebut dijadikan dalam kehidupan seharihari.

\section{b. Aspek Motivasi}

Masa remaja merupakan masa dimana seorang anak mulai dihadapkan pada relaita kehidupan. Pada saat inilah jiwa seoarang remaja mengalami peralihan dari jiwa kekanak-kanakan kearah pendewasaan. Dalam masa peralihan ini tentunya anak banyak mengalami peristiwa baru yang selama ini belum pernah dialami pada masa sebelumnya. Peralihan keadaan inilah yang dapat memicu timbulnya dorongan untuk mencoba hal-hal baru yang selama ini belum pernah mereka coba, tentunya tanpa pemikiran yang matang tentang akibat-akibat yang bisa ditimbulkan karena keterbatasan pemikiran pada usia dewasa. Menurut Sarwono dalam Darmasih, (2009) yang menjelaskan bahwa motivasi adalah dorongan bertindak untuk memuaskan suatu kebutuhan, dorongan dalam motivasi diwujudkan dalam bentuk tindakan. Darmasih, (2009) yang menjelaskan bahwa apabila orang-orang yang terlibat saling mencintai ataupun saling terikat menganggap bahwa hubungan seks sebelum menikah dianggap "benar".

\section{Faktor Eksternal}

Faktor eksternal merupakan faktor yang datang dari luar individu, yang dapat mendorong remaja untuk melakukan seks bebas. Dalam hal ini penulis menemukan beberapa faktor eksternal yang mempengaruhi fenomena yang terjadi. Terdapat beberapa faktor eksternal, diantaranya:

a. Aspek Keluarga

Di dalam keluarga jelas dibutuhkan adanya komunikasi terutama orang tua dengan anak-anaknya, karena hal tersebut dapat memberikan kehangatan dan hubungan yang baik antara orang tua dan anak. Dengan 
adanya komunikasi, orang tua dapat memahami kemauan dan harapan anak, demikian pula sebaliknya. Sehingga akan tercipta adanya saling pengertian dan akan sangat membantu di dalam memecahkan atau mencari jalan keluar dari persoalan yang dihadapi anaknya. Komunikasi merupakan hal yang penting dalam keluarga, karena dengan komunikasi dalam suatu keluarga terlihat adanya interaksi, hubungan yang akrab antar keluarga.Berbeda halnya ketika seorang anak berada pada keluarga yang kurang adanya komunikasi antara orang tua dengan anak. Hal ini dapat mengakibatkan anak akan merasa kesepian di dalam keluarga. Kartono (2009) yang menjelaskan bahwa keluarga memiliki pengaruh yang luar biasa besarnya dalam pembentukan watak dan kepribadian anak. sesuai dengan pendapat Taris dan Senim dalam (Puspitasari, 2012) yang berpendapat bahwa remaja yang tidak memiliki hubungan erat dan pengawasan dengan orang tua cenderung terlibat dalam hubungan seksual pranikah.

b. Aspek Pergaulan

Bagi remaja seorang teman merupakan suatu kebutuhan, sehingga terkadang teman dianggap sebagai "orang tua kedua" bagi remaja. Dorongan untuk memiliki teman dan membentuk suatu kelompok juga dapat dipandang sebagai usaha agar tidak tergantung dengan orang yang lebih dewasa atau sebagai tindakan nyata dalam interaksi sosial. Maka didalam lingkungan pergaulan remaja selalu kita temukan adanya kelompok teman sebaya. Pergaulan dengan teman sebaya dapat membawa seseorang kearah positif dan negatif. Aspek positifnya adalah tersedianya saluran aspirasi, kreasi, pematangan kemampuan, potensi dan kebutuhan lain sebagai output pendidikan orang tua dan potensinya. Akan tetapi jika yang dimasukinya adalah lingkungan yang buruk maka akan mendorong mereka kepada hal negatif. Pergaulan dengan teman sebaya yang di dalamnya terdapat keakraban dan adanya intensitas pertemuan yang tinggi dapat memberikan pengaruh terhadap individu lain di dalam kelompok tersebut. A.Islami, (2012) menjelaksan bahwa dengan adanya ikatan secara emosional dalam kehidupan peer group akan mendapatkan berbagai manfaat dan pengaruh yang besar bagi individu yang berada dalam kelompok tersebut. Misalnya timbul rasa penasaran dan keinginan untuk mencoba kebiasaan yang dilakukan oleh salah satu individu dalam kelompok tersebut. Hal tersebut akan berdampak positif ketika individu di dalam kelompok pergaulan meniru kebiasaan yang dilakukan oleh salah satu teman kelompoknya yang melakukan perbuatan positif. Berbeda halnya ketika individu tersebut meniru perbuatan yang 
negatif dari salah satu teman di dalam kelompoknya, maka kemungkinan besar individu tersebut akan meniru perbuatan negatif dari temannya. Hal ini sesuai dengan pendapat Adamassasmita dalam A.Islami, (2012) yang menjelaskan bahwa remaja yang terlibat dengan tingkah laku delinquent akan mengarah kepada tingkah laku delinquent yang dibawa oleh temanteman sebayanya. Keadaan ini disebabkan karena tingkat keakraban yang dekat dan intensitas pertemuan yang tinggi.

c. Aspek Media Massa

Dampak yang ditimbulkan oleh media massa bisa beraneka ragam diantaranya, misalnya terjadinya perilaku yang menyimpang dari norma-norma sosial atau nilai-nilai budaya yang ada. Pengaruh media massa baik televisi, majalah, handphone dan internet sering kali di salah gunakan oleh kaum remaja dalam berperilaku sehari-hari, misalnya saja remaja yang sering melihat tontonan kebudayaan barat, mereka melihat perilaku seks itu menyenangkan dan dapat diterima dilingkungannya. Kemudian dari hal tersebutlah kaum remaja mulai mengimitasikan pada pola kehidupan mereka sehari-hari. Kedua informan pokok perempuan memiliki kebiasaan menonton film barat yang di dalamnya di isi oleh adeganadegan seks yang menurut mereka hal tersebut merupakan suatu hal yang romantis. Dari anggapan tersebutlah sehingga sesuai dengan pendapat Jones dalam Singarimbun (1997) yang menjelaskan bahwa media massa seperti film, musik, bacaan dan televisi telah mengajarkan kepada mereka bahwa seks itu romantis, merangsang dan menggairahkan.

Berdasarkan pembahasan diatas dapat diterjemahkan bahwa dalam aspek motivasi hendaknya kaum remaja harusnya memiliki motivasi yang positif, guna meningkatkan kualitas dan kuantitas bagi dirinya. Selain itu juga dalam aspek pergaulan, hendaknya remaja lebih memperhatikan mengenai pergaulannya, sehingga remaja mampu untuk memilah dan memilih pergaulan yang membawa dampak positif dan negatif bagi dirinya. Dalam aspek media massa pula juga hendaknya remaja menggunakan sarana media massa ke arah yang lebih positif sehingga tujuan dari adanya media massa lebih tepat sasaran.

\section{KESIMPULAN}

Masa remaja merupakan masa dimana seorang individu mengalami peralihan dari satu tahap ke tahap berikutnya dan mengalami perubahan baik emosi, tubuh, minat, pola perilaku, dan juga penuh dengan masalah-masalah dan seks bebas merupakan hubungan yang dilakukan oleh laki-laki dan perempuan tanpa adanya ikatan perkawinan. Berdasarkan penelitian dan sumber-sumber yang penulis angkat yang mana fenomena prilaku seks bebas dikalangan remaja ini saat ii mencapai puncak yang sangat tinggi hingga fenomena prilaku seks bebas perlu 
menjadi kajian lebih lanjut bagi para akademisi serta untuk membantu bagi pemerintah memberikan solusi yang lebih baik dan juga memberikan masukkan kepada para orang tua untuk lebih waspada dan memperhatikan anak remaja mereka yang dalam masa pertumbuhan di zaman teknologi dan informasi yang lebih mudah di dapat.

Berdasarkan pembahasan yang penulis kemukan dalam penyimpangan prilaku sosial seks bebas di kalangan remaja yang mana penulis mengambil tiga pembahasan yang menjadi garis beras untuk menjawab sejauh mana fenomena penyimpangan sosial dalam prilaku seks bebas dikalangan remaja dikalangan remaja, yaitu : 1. Pengetahuan remaja tentang seks bebas. 2. Prilaku seks bebas dikalangan remaja. 3. Faktor penyebab seks bebas dikalagan remaja.

Sehingga penulis menemukan dan dianalisis berdasarkan teori Differential Assosiation Edwar H.Sutherland mendapatkan beberapa hal yang dalam fenomena penympangan sosial dalam prilaku seks bebas dikalangan remaja antara lain, yaitu:

1. Pendidikan seks sangat berpengaruh terhadap prilaku seks bebas dilakangan remaja untuk sebelum dan sesudah pencegahan seks bebas meskipun penulis juga menemukan faktor-faktor lain seperti pengalaman pribadi remaja dan pengaruh orang lain yang dianggap penting dalam pencegahan penyimpangan sosial seks bebas dikalangan remaja.
2. Prilaku seks bebas diklangan remaja dilakukan dengan berbagai tindakan atau prilaku seks bebas beresiko yang terdiri atas tahapan-tahapan tertentu antara lain, dimulai dengan pegang tangan, cium kening, cium basah atua cium bibir, berpelukan, memegang atau meraba bagian sensitif, petting, oral seks, dan bersenggama.

3. Faktor penyebab seks bebas dikalangan remaja, banyak faktor ditemukan oleh para ahli dalam memberikan pemahaman dan masukkan guna untuk mencegah prilaku seks bebas dikalngan remaja ini semakin tinggi diantaranya. Menurut Grifari (2003), ada empat faktor menjadi sumber penyimpangan tersebut, yaitu : a. Kualitas diri remaja itu sendiri, b. Kualitas keluarga yang tidak mendukung anak berlaku baik, c. Kualitas lingkungan yang kurang sehat, d. Kurangnya kualitas informasi yang masuk pada remaja. Sedangkan menurut penelitian oleh Kaiser Famly Foundation dalam Dariyo, (2004), hal-hal yang mendorong remaja melakukan seks bebas adalah: a. Hubungan seks ( bentuk penyaluran kasih sayang yang salah dalam masa pacaran), b. Kehidupan iman yang rapuh, c. Faktor kematangan biologis. Selain itu Kartono, (2005), mengungkapkan bahwa prilaku seks bebas dipengaruhi oleh: a. Belum adanya regulasi atau peraturan terhadap penyelanggaraaan hubungan seks, $b$. 
Perubhan sosial. Serta berdasarkan beberapa artikel yang juga penulis kutip yang mana dalam memmbagi faktor penyebab seks bebas dikalangan remaja terbagi menjadi dua faktor, yaitu: a. Faktor Internal ( aspek perkembangan alat seksual dan aspek motivasi), b. Faktor Eksternal (Aspek keluarga, aspek pergaulan dan aspek media masa).

Perbedan tingkat pengetahuan dan sikap remaja dalam pencegahan seks bebas sebelum dan sesudah di berikan pendidikan seks. Pendidikan seks dalam penelitian ini untuk meningkatkan tingkat pengetahuan dan menurunkan sikap terhadap seks bebas pada remaja, lebih dikarenakan faktor-faktor lain yang terdapat pada penelitian ini, diantaranya pengalaman pribadi remaja dan pengaruh orang lain yang dianggap penting. Dengan demikian dapat diharapkan bahwa untuk pemberian pendidikan seks dapat lebih efektif dalam meningkatkan pengetahuan dan sikap remaja dalam pencegahan seks bebas. Perilaku seks bebas di kalangan remaja dilakukan dengan berbagai tindakan atau Perilaku seks bebas beresiko yang terdiri atas tahapan-tahapan tertentu yaitu dimulai dari berpegangan tangan, cium kering, cium basah, berpelukan, memegang atau meraba bagian sensitif, petting, oral sex, dan bersenggama (sexual intercourse). Perilaku seks bebas pada remaja ini pada akhirnya dapat mengakibatkan berbagai dampak yang merugikan remaja itu sendiri.

Serta berdasarkan pembahasan dapat diterjemahkan bahwa dalam aspek motivasi hendaknya kaum remaja harusnya memiliki motivasi yang positif, guna meningkatkan kualitas dan kuantitas bagi dirinya. Selain itu juga dalam aspek pergaulan, hendaknya remaja lebih memperhatikan mengenai pergaulannya, sehingga remaja mampu untuk memilah dan memilih pergaulan yang membawa dampak positif dan negatif bagi dirinya. Dalam aspek media massa pula juga hendaknya remaja menggunakan sarana media massa ke arah yang lebih positif sehingga tujuan dari adanya media massa lebih tepat sasaran.

\section{DAFTAR PUSTAKA}

Amrillah. 2006. Perilaku Seksual dan Seksualitas. Surakarta: UMS Press.

Baswori \& Kasinu A. 2007. Metodologi Penelitian Sosial. Kediri: CV Jenggala Pustaka Utama.

BKKBN. 2010. Penyimpangan Kehidupan Berkeluarga Bagi Remaja. Jakarta: BKKBN

Boediono. 2010. Perbedaan Tingkat Pengetahuan Dan Sikap Remaja Tentang Seksual Pranikah Sebelum Dan Setelah Diberi Pendidikan Seks Di SMA N 2 Maranggen Demak. Skripsi. Program Studi S1Keperawatan Fakultas Ilmu Keperawatan dan Kesehatan Universitas Muhammadiyah Semarang

BPS, BKKBN, Kementerian Kesehatan RI, ICF International. 2013. Survei Demografi dan Kesehatan Indonesia 2012 : Kesehatan Reproduksi Remaja. Jakarta: BPS, BKKBN, Kemenkes, ICF International. 
Budi, Andayani. 2005. Kepuasan Pernikahan Ditinjau dari Berpacaran dan Tidak Berpacaran. Jurnal Psikologi. Volume 32, No. 2, 101-111.

Cunigham, F. Gary. 2012. Obstetri Williams. Jakarta: EGC.

Dariyo, Agoes. 2004. Psikologi Perkembangan Dewasa Muda. Jakarta: Grasindo

Darmasih, Ririn. 2009. Faktor Yang Mempengaruhi Perilaku Seks Pranikah Pada Remaja SMA Di Surakarta. Surakarta: Universitas Muhammadiyah Surakarta

Desmita. 2005. Psikologi Perkembangan. Bandung: PT. Remaja Rosdakarya.

Ghifari, A A. 2003. Gelombang Kejahatan Seks Remaja Modern. Bandung: Mujahid Press.

Gunarsa, Singgih D, 1988, Psikologi Pelajar, Jakarta, BPK Gunung Mulya.

Hurlock, Elizabeth, B. 2011. Psikologi Perkembangan. Jakarta: Erlangga.

Islami, Alam, Mahbub, M. 2012. FaktorFaktor Eksternal Yang Menyebabkan Siswa Sma Bermain Game Online Beserta DampakDampaknya. Jember: Universitas Jember.

Kartono, Kartini. 2009 Psikologi Abnormal dan Abnormalitas Seksual, Yogyakarta: Jalan Sutra.

Kemenkes RI, 2015. Info data Situasi Kesehatan Reproduksi Remaja, Jakarta Selatan: Kemekes RI.

KPAI, 2016. Data Kasus Pengaduan Anak Berdasarkan Klaster Perlindungan Anak. (46).
Lubis, D.P.U., 2017. Peran Teman Sebaya dan Paparan Media Pornografi Terhadap Perilaku Seksual Remaja Di Sekolah Tinggi Ilmu Kesehatan Yogyakarta. Jurnal Kesehatan " Samodra Ilmu, 8(1), pp.47-54.

Masland, P.R. 2004. Apa yang ingin diketahui remaja tentang seks. Jakarta : Bumi Aksara

Mubarak,Wahid Iqbal.2009. Sosiologi untuk Keperawatan.Jakarta: SalembaMedika.

Narbuko, C. \& Achmadi. 2005. Metodologi Peneltian. Jakarta: PT Bumi Aksara.

Narwoko, J. Dwi dan Bagong Suyanto. 2004. Sosiologi Teks Pengantar dan Terapan. Jakarta: Prenada Media Group.

Puspitasari, Cyntia, T. 2012. Sikap Remaja Terhadap Hubungan Seksual Pranikah Ditinjau Dari Keterbukaan Dengan Orang Tua. Semarang: Universitas Katolik Soegijapranata.

Rahmawati, Dian. 2012. Kontrol Sosial MasyarakatTerhadap Perilaku Seks Pranikah Mahasiswa Di Rumah Kost. Jember: Universitas Jember

Rumini, Sri dan Siti Sundari. 2004. Perkembangan Anak dan Remaja. Jakarta: PT Rineka Cipta

Santrock, J. W. 2003. Adolescence (Perkembangan Remaja) Terjemahan Edisi 11. Jakarta: Erlangga

Sarwono, S. W. 2010. Psikologi Remaja. Jakarta: Raja Grafindo Persada. 
Setiyaningrum, E., 2015. Pelayanan Keluarga Berencana dan Kesehatan Reproduksi, Jakarta: Trans Info Media.

Stuart G.W. and Sundeen S.J. 1999. Principles and Practice of Psychiatric Nursing. New York : Mosby Year Book, Inc.

Sumiati, Dinarti, Nurhaeni, Dan Aryani. 2009. Kesehatan Jiwa Remaja Dan Konseling. Jakarta: Trans Indo Media.

Sunarwiyati,S. 1985. Pengukuran Sikap Masyarakat terhadap Kenakalan Remaja di DKI Jakarta.

Surya \& Indrawati. 2011. Perbedaan Tingkat Pengetahuan Remaja Tentang Kesehatan Reproduksi Sebelum Dan Sesudah Penyuluhan Di SMA Negeri 2 Ungaran Kabupaten Semarang Tahun 2011. Jurnal Kebidanan, Vol.4 No. 02 Desember 2012

Suwarni. 2009. Monitoring Parenataldan dan Perilaku Teman Sebaya Terhadap Perilaku Seksual Remaja SMA di Kota Pontianak. Jurnal Promosi Kesehatan Indonesia Vol. 4 No.2 Agustus 2009

Tanjung, Armaidi. 2007. Free Sex No! Nikah Yes. Jakarta: Amzah.

Wawan \& Dewi. 2010. Pengetahuan, Sikap dan Perilaku Manusia. Yogyakarta :Nuha Medika.

Widodo. 2004. Cerdik Menyusun Proposal Penelitian. Jakarta: Yayasan Kelopak.

Widyastuti, Y. 2009. Kesehatan Reproduksi. Yogyakarta : Fitramaya
Zed, M. 2014. Metode Penelitian Kepustakaan. Jakarta: Yayasan Obor Indonesia. 